\title{
Keystone intimidators in the intertidal: non-consumptive effects of a keystone sea star regulate feeding and growth in whelks
}

\author{
J. Stephen Gosnell ${ }^{1, *}$, Steven D. Gaines ${ }^{1,2}$ \\ ${ }^{1}$ Department of Ecology, Evolution, and Marine Biology, and ${ }^{2}$ Bren School of Environmental Science and Management, \\ University of California, Santa Barbara, California 93106, USA
}

\begin{abstract}
Predators can exert strong controls on community structure through both consumptive and non-consumptive effects. When one of these impacts on diversity is large, such predators have been labeled keystone predators and keystone intimidators respectively. Here we demonstrate that some predators play both roles simultaneously. We studied the species for which the term keystone predator was originally coined, the ochre sea star Pisaster ochraceus. We observed non-consumptive effects that were not mediated through its well-known invertebrate prey, the competitive dominant mussel Mytilus californianus, but instead through whelks Nucella emarginata, another important intertidal predator. Whelks exposed to effluent from stars in the laboratory consumed significantly less, grew significantly less, and developed less reproductive and digestive tissue. Star presence also altered the feeding preferences of whelks. Results suggest these responses are non-linear with respect to the number of predators and thus predator presence may be a larger determinant of non-consumptive effects than density. A second experiment found, in agreement with previous field surveys, that these large non-consumptive effects occurred even though whelk mortality due to consumption by stars is extremely low. These results offer a new mechanism to explain previous field experiments that found whelks have little impact on mussel mortality in the presence of stars yet large effects when stars are absent. They demonstrate the potential for non-consumptive effects to play a major role in community regulation by a keystone predator. They also demonstrate that non-consumptive interactions may have large effects on species even when rates of consumptive mortality are exceedingly low.
\end{abstract}

KEY WORDS: Keystone $\cdot$ Non-consumptive effects $\cdot$ Pisaster $\cdot$ Nucella $\cdot$ Mytilus $\cdot$ Rocky intertidal Resale or republication not permitted without written consent of the publisher

\section{INTRODUCTION}

A large body of ecological theories has focused on the ability of predators to regulate prey populations and influence overall community diversity. Although theories have traditionally highlighted the effects of predators due to consumption (Hairston et al. 1960, Paine 1966, Holt et al. 1994), potential prey may also respond to the presence of a predator by altering their morphology, behavior, physiology, or life history strategies (Relyea 2001, Werner \& Peacor 2003,
Miner et al. 2005, Freeman 2007, Peckarsky et al. 2008a, Sheriff et al. 2009). These non-consumptive effects, which have also been described as effects of fear (Trussell et al. 2006) and intimidation (Preisser et al. 2005), predator avoidance effects (Alexander \& Covich 1991), non-lethal effects (Lima 1998), and trait-mediated interactions (Abrams 2007), may be ubiquitous and have major impacts on prey species and communities (Trussell et al. 2003, Preisser et al. 2005). However, studies commonly compare the relative effects of non-consumptive and consumptive 
interactions and thus focus on the importance of nonconsumptive effects among species that commonly consume each other (Trussell et al. 2003, Preisser et al. 2005). Less attention has been given to the potential impacts of non-consumptive interactions among predators and rarely consumed prey, or to the potential for predators to simultaneously influence multiple prey species through both consumptive and nonconsumptive effects.

Non-consumptive interactions may occur largely in the absence of consumptive interactions in communities where prey possess costly anti-predator adaptations that substantially reduce their risk of consumption but also reduce prey performance (Sih et al. 2010). For example, parasitic phorid flies have been shown to reduce foraging behavior by more than $50 \%$ in potential ant hosts despite an observed infection level of $3 \%$ (Morrison 1999). Predominantly nonconsumptive interactions may also be common in communities where predators encounter a variety of prey that differ in density, handling time, or predator preference ranking, or in communities where prey respond to non-specific alarm cues and thus overestimate predation risk (Sih et al. 2010). Predators can also alter population dynamics in rarely consumed species through the 'remote effect' (Orrock et al. 2010) by driving changes in prey movement or migration. Importantly, traditional methods used to study predator-prey interactions (e.g. gut content, isotope analysis) may miss these interactions, and non-consumptive interactions are often not considered in ecological theory (Sih et al. 2010).

Ironically, our motivation for considering predominantly non-consumptive interactions comes from previous studies on the species that originally motivated the concept of a keystone predator (Paine 1969). By consuming the competitive dominant space occupier, ochre sea stars Pisaster ochraceus prevent a single species from monopolizing available space and increase overall community diversity. However, stars may also influence other intertidal species. Previous field studies on the Oregon coast have noted that although whelks Nucella canaliculata and $N$. emarginata (and likely $N$. ostrina; see Marko et al. 2003) may fill the role of top predator in the absence of sea stars, they do not impact mussel mortality in the presence of stars (Navarrete \& Menge 1996). Subsequent studies have suggested that competition among whelks and stars, and not intraguild predation, may lead to the observed change in whelk impact on mussel mortality (Navarrete et al. 2000). However, the number of mussels typically observed in natural communities suggests predators are likely not food-limited. The possibility exists that although stars rarely consume whelks (Sanford 1999), they may impact whelk consumption through nonconsumptive interactions. Supporting this assertion, studies have also shown that the presence of ochre sea stars and other star species elicit behavioral and morphological responses in multiple intertidal species (Margolin 1964, Phillips 1978, Bryan et al. 1997, Sanford 1999, Freeman 2007, Bourdeau 2009a). Nonconsumptive effects have previously been found to play a key role in other intertidal communities (Trussell \& Smith 2000, Trussell et al. 2004, 2006). Stars may therefore act simultaneously as keystone consumers and keystone intimidators through their effects on mussels and whelks, respectively (Peckarsky et al. 2008a). To explore the role non-consumptive effects may play in community regulation by keystone stars, we evaluated how the presence of sea stars Pisaster ochraceus impacted growth, feeding, and development of reproductive tissue in whelks Nucella emarginata.

\section{MATERIALS AND METHODS}

In the fall of 2009, sea stars, whelks, and mussels were collected from sites around the University of California, Santa Barbara. Whelk and mussel species used in this study (Nucella emarginata and Mytilus californianus) are California congeners for species used in previous Oregon field studies and have similar functional roles in intertidal communities. Specimens were used in a 8 wk growth study to determine if star presence altered whelk growth, feeding rates, and reproductive tissue mass. Following this initial experiment, the impact of prior star exposure on the ability of whelks to avoid consumption by stars was investigated using a subset of whelks from the first experiment.

To determine the impact of star presence on whelk feeding, growth, and reproductive tissue mass, 120 mussels (30 each from 4 size classes: <15, 15-30, $30-45$ and $45-60 \mathrm{~mm}$ ) and 20 whelks were placed in 1.51 containers set in a sea water table. Whelk densities were chosen to replicate those observed in surrounding areas (J. S. Gosnell pers. obs.). The design also simulated natural whelk habitat: whelks normally aggregate in and among mussel beds which may vary in thickness but normally contain larger mussels with newer recruits in and among them. Drainage holes placed approximately $10 \mathrm{~cm}$ from the top of the containers allowed outflow while preventing water from mixing between treatments (Freeman 
2007). Water entering these containers first flowed through a separate container containing 0,1 , or 2 stars ( $\mathrm{n}=4$ replicates for each treatment). Since previous experiments suggested whelk growth could be observed over a period of several months, the experiment was monitored for 56 d (Sanford 2002, Bourdeau 2009b). Fresh filtered seawater continuously entered the predator compartment and flowed into the container containing the whelks and mussels. A separate control treatment containing no stars or whelks was used to measure mussel mortality due to experimental set-up. Four whelks were added to the star containers every 2 wk to serve as a food source and to standardize the impact of any chemical cues released by the whelks (Relyea 2003).

Whelk consumption of mussels was measured by counting the number of dead mussels found in each container at the conclusion of the experiment. In order to determine whelk growth, whelks were individually numbered at the beginning of the experiment using acrylic paint pens; markings were subsequently sealed with acrylic adhesive (Freeman 2007). The outer margin of each whelk shell was also marked. Mass and total shell length (from siphonal canal to shell apex) were measured at the beginning and end of the experiment. Length was measured to the nearest $0.001 \mathrm{~cm}$ and mass was measured to the nearest $0.001 \mathrm{~g}$. Linear shell growth, or the distance from the original to the new shell margin, was also measured to the nearest $0.001 \mathrm{~cm}$ at the end of the experiment (Bourdeau 2009b).

In order to determine the impact of exposure to stars on whelk digestive and reproductive tissue, a subset of whelks from each treatment were dissected ( $\mathrm{n}=26$ for 0 and 1 star treatment, $\mathrm{n}=22$ for 2 star treatment). Since the gonad and digestive tissues proved difficult to separate, the conjoined stomach and reproductive tissue complex was removed and weighed (Hechinger et al. 2008). To assess the relative production of each tissue, a 100-point grid was randomly overlaid on a digital image of the combined tissue compressed between 2 glass slides using ImageJ image processing software, (Abramoff et al. 2004). Tissue identity (gonad or digestive) was assessed at each grid point.

To determine how the consumption of whelks by stars changed with star density and if previous exposure to stars impacted whelk's ability to avoid predation, a second experiment was conducted using the remaining whelks from the growth experiment. Ten marked whelks from a single treatment group in the first experiment $(0,1$, or 2 stars $)$ were placed in tanks containing 1 or 2 newly collected stars and sufficient mussel cover to simulate natural habitat (mussel layers were approximately $5 \mathrm{~cm}$ thick). Trial size was limited due to the number of whelks available from the previous experiment: 3 trials were carried out with each treatment group being exposed to 1 star, and 2 trials were carried out with each treatment group being exposed to 2 stars. Consumption by stars was measured as whelk mortality after $2 \mathrm{~d}$.

All data were analyzed using R version 2.12 (R Development Core Team 2010). To account for possible similarities in whelks housed in the same container, containers were considered a random factor in all analyses stemming from the first experiment (whelk feeding, growth measures, and tissue production and allocation) using the lme4 package (Bourdeau 2009b, Bates et al. 2011). Since the final states of mussels (dead or alive) and the number of grid points found on digestive and reproductive tissue are binomial data, the impacts of predator density and mussel size on whelk feeding and tissue allocation were analyzed using a mixed-effects generalized linear regression model. The impacts of predator presence on whelk growth (calculated as the sum of changes in length and mass and linear shell growth) and tissue (the total mass of gonad and reproductive tissues) measurements were analyzed using linear mixedeffects models; heterogeneity among treatment groups was considered using Levene's test and logarithmic transformations of data were carried out if significant differences were found. Impact of fixed factors was compared using likelihood ratio tests conducted on models fit using maximum likelihood (Crawley 2007, Zuur 2009). When significant differences were detected among treatments, orthogonal contrasts were used to compare the impact of sea star presence (comparing treatments with and without sea stars) and sea star density (comparing only treatments that contained sea stars) using the multcomp package in R (Hothorn et al. 2008). Data from the predation trials were analyzed using a generalized linear regression model to determine if star density or previous exposure to stars impacted whelk mortality.

\section{RESULTS}

Whelks housed in the presence of sea stars exhibited greatly reduced feeding, growth, and tissue development, but increasing the density of stars had only marginal or insignificant effects on whelk traits (Fig. 1). Both star presence and mussel size impacted the consumption of mussels by whelks. Analysis revealed a marginally significant interaction $\left(\chi_{6}^{2}=\right.$ 
10.90, $\mathrm{p}=0.09$ ) between predator treatment and mussel size. This suggests that the size and number of mussels consumed by whelks differed based on predator treatment (Fig. 2). To investigate this interaction, whelk feeding was analyzed separately for each predator treatment. Mussel size was highly significant in predicting mussel mortality when whelks were not exposed to effluent from stars $\left(\chi^{2}{ }_{3}=30.06\right.$, $\mathrm{p}<0.001)$. However, mussel size only marginally impacted mortality when whelks were exposed to star effluent (for 1 star treatment: $\chi^{2}{ }_{3}=7.40, \mathrm{p}=0.06$; for 2 star treatment: $\chi_{3}^{2}=6.47, \mathrm{p}=0.09$ ). In general, the presence of stars decreased preferential feeding by whelks based on mussel size, with whelks demonstrating less prey selectivity. All replicates had remaining live mussels, suggesting whelk growth was not food limited.

Significant differences were found for all growth and tissue development measures based on predator treatments (Table 1). Orthogonal contrasts revealed that although star presence had highly significant negative impacts on all measured traits $(p<0.01$ in all cases), increasing the density of stars had mar- ginal effect on changes in length and mass $(p=0.049$ and $\mathrm{p}=0.09$, respectively) and no effect on shell and tissue growth $(\mathrm{p} \gg 0.10)$. In the absence of stars, growth in mass, overall length, and new shell length were 2.91 (0.39 vs. $0.13 \mathrm{~g}), 3.92$ (0.87 vs. $0.22 \mathrm{~mm}$ ), and 10.45 (2.14 vs. $0.21 \mathrm{~mm}$ ) times higher on average than in treatments with stars. Whelks in the presence of stars had $0.076 \mathrm{~g}$ less reproductive and digestive tissue and $2.6 \%$ less of their mass in these tissues. If only tissue mass was considered (excluding the mass of the shell), whelks in the presence of stars had $5 \%$ less of their total tissue mass in digestive and reproductive tissue. Predator treatment, however, did not impact relative production of these tissues (analyzed as number of grid points for each tissue type, $\chi_{2}^{2}=$ 1.2959, $\mathrm{p}=0.52$ ).

In the experiment examining star consumption of whelks, only 1 whelk was consumed out of a total of 150 whelks that could have been consumed. Therefore, neither the number of stars nor previous exposure to stars had a significant impact on whelk mortality (number of stars: $\mathrm{p}=0.17, \chi^{2}{ }_{1}=1.8$; previous exposure: $\left.\mathrm{p}=0.33, \chi^{2}{ }_{2}=2.1646\right)$. However, stars were
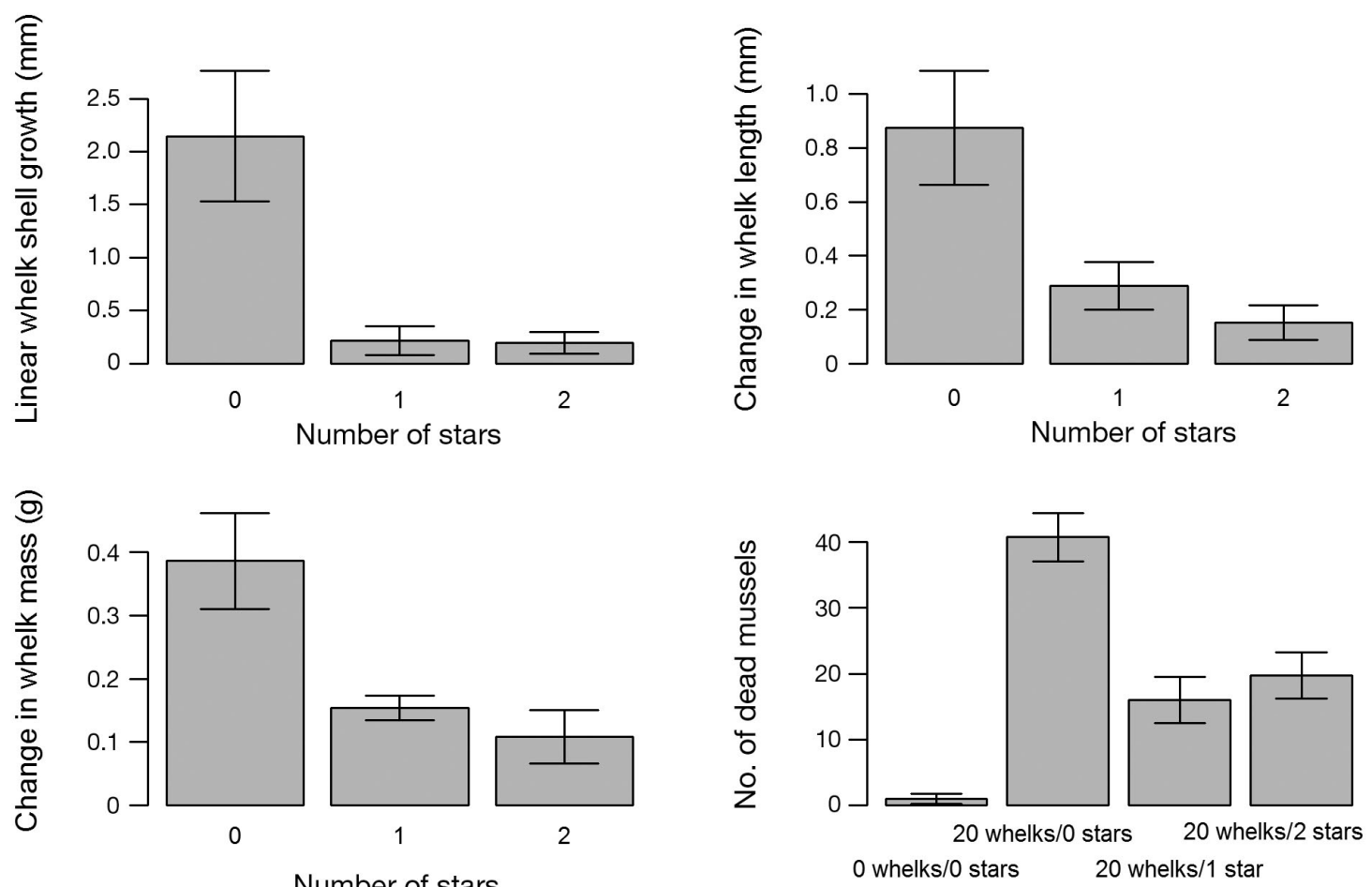

Number of predators

Fig. 1. Effects of the presence of the ochre sea star Pisaster ochraceus on growth of whelks Nucella emarginata and predation by whelks on mussels Mytilus californianus. In the experiment, 20 whelks were held in tanks with mussels and 0, 1 or 2 sea stars. A control tank contained only mussels. Error bars represent $95 \%$ confidence intervals 


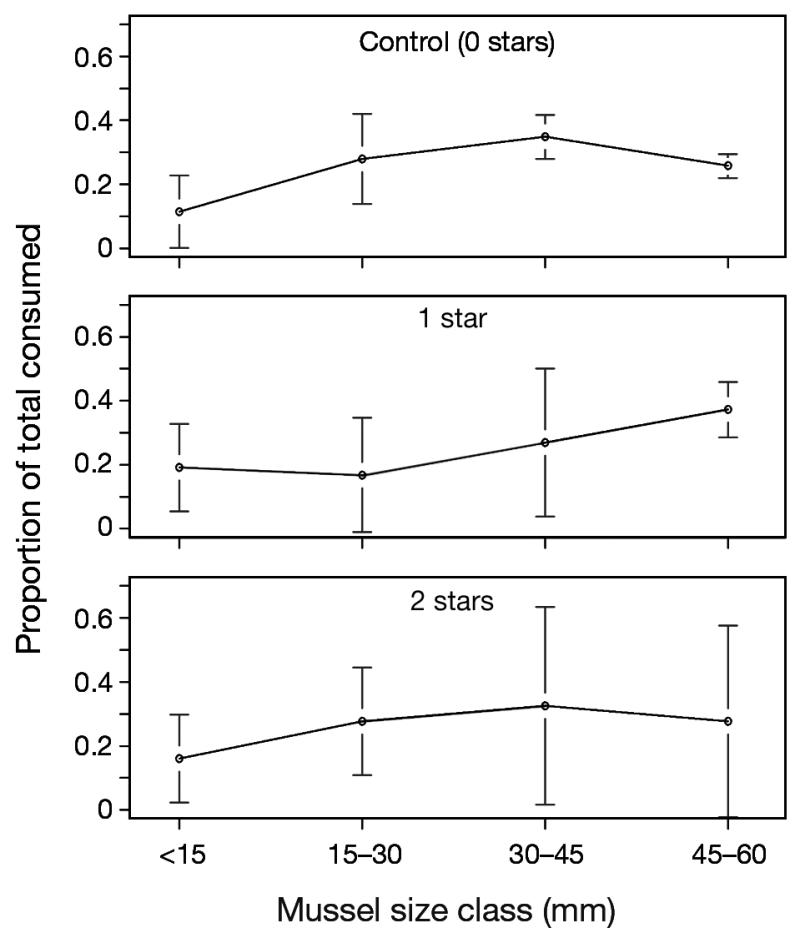

Fig. 2. Consumption of mussels by whelks in tanks containing 0,1 and 2 sea stars. The presence of sea stars reduces prey selectivity of whelks based on mussel size. Lines represent $95 \%$ confidence intervals

noted to consume mussels throughout the experiment, suggesting hunger and feeding activity were common in the trials.

\section{DISCUSSION}

This study was motivated by extensive prior field studies showing that whelks have strong effects on their mussel prey only when the keystone predatory sea star Pisaster ochraceus was absent (Navarrete \& Menge 1996). Our findings suggest that reduced whelk feeding is likely due to a non-consumptive in- teraction with stars. Whelks raised in water previously exposed to stars fed less, grew less, and had less overall reproductive and digestive tissue, and star presence also modified whelks' feeding preferences. These effects occurred despite the fact that stars rarely consume whelks even in constrained laboratory settings that limit the potential of whelks to avoid consumption, just as they rarely consume them in the field (Sanford 1999). Since the presence of stars reduces consumption in a predator that would otherwise consume mussels, the net impact of predators on this community is effectively reduced due to nonconsumptive interactions among these predators.

Results also suggest reduced feeding by whelks in the presence of stars may lead to decreased growth and reproductive capacity. By reducing reproductive tissue mass, the presence of stars may reduce reproductive output of individuals or limit reproduction in areas that maintain a standing population of stars. This suggests non-consumptive interactions among sea stars and whelks may have long-term impacts on both whelk and mussel population dynamics. Similar results have been observed in other systems (Nelson et al. 2004, Pangle et al. 2007, Peckarsky et al. 2008b). For example, the introduction of wolves to Yellowstone has been suggested to reduce reproduction in various prey (Creel et al. 2009, Laporte et al. 2010), including impacts precipitated to lower trophic levels through the threat of intraguild predation on coyotes (Berger et al. 2008, Creel \& Christianson 2009).

This study demonstrates the potential importance of non-consumptive interactions among predators and rarely consumed prey. Predominantly nonconsumptive interactions may be particularly important in communities with multiple predator species, with non-consumptive interactions influencing the effects of both species on prey and possibly explaining some emergent properties of multiple predators (Sih et al. 1998, Jiang \& Krumins 2006). Previous work has noted non-consumptive effects of predators

Table 1. Statistical comparisons (see text for details) of effects of presence and density of ochre sea stars Pisaster ochraceus on whelks Nucella emarginata, based on growth and tissue measurements

\begin{tabular}{|c|c|c|c|c|c|c|c|}
\hline \multirow[t]{2}{*}{ Trait } & \multicolumn{3}{|c|}{$\begin{array}{c}\text { Impact of predator } \\
\text { treatment }\end{array}$} & \multicolumn{2}{|c|}{$\begin{array}{c}\text { Impact of } \\
\text { predator presence }\end{array}$} & \multicolumn{2}{|c|}{$\begin{array}{c}\text { Impact of } \\
\text { predator density }\end{array}$} \\
\hline & $\chi^{2}$ statistic & $\mathrm{df}$ & $\mathrm{p}$ & $Z$ & $\mathrm{p}$ & $Z$ & $\mathrm{p}$ \\
\hline Change in mass & 14.201 & 2 & $<0.001$ & 4.621 & $<0.001$ & 1.712 & 0.09 \\
\hline Change in length & 21.653 & 2 & $<0.001$ & 6.983 & $<0.001$ & 1.969 & 0.049 \\
\hline Shell growth & 26.573 & 2 & $<0.001$ & 8.926 & $<0.001$ & -0.344 & 0.73 \\
\hline Mass of gonad and digestive tissue & 12.665 & 2 & 0.002 & 4.419 & $<0.001$ & 0.335 & 0.73 \\
\hline Proportion of mass in gonad and digestive tissue & 12.246 & 2 & 0.002 & 4.146 & $<0.001$ & -0.151 & 0.88 \\
\hline
\end{tabular}


may be overlooked when they cause changes in the same direction as consumptive effects (Peckarsky et al. 2008a); likewise, effects of non-consumptive interactions among predators may be misinterpreted as resulting from competition in predator-removal experiments. Fully non-consumptive interactions should also be considered in communities that contain multiple prey species with similar evolutionary histories or in communities where predation risks differ among sites. Previous work suggests that although local adaptation may occur in prey responses due to predator presence (Storfer \& Sih 1998, Laurila et al. 2006, Kishida et al. 2007), these responses may not precisely match current predation risk due to phylogenetic inertia (Espoz \& Castilla 2000), predator-induced migration (Orrock et al. 2010), changes in predator exposure over time (Hoverman \& Relyea 2007, Ireland et al. 2007), or changing predation pressure among communities, suggesting a possible swamping-out of local adaptation or lack of graded response to risk (Escobar \& Navarrete 2011). Overall, these results demonstrate the importance of considering non-consumptive interactions among multiple species in determining the potential contribution of non-consumptive effects to total predator community impact.

Coupled with previous studies documenting direct predation by stars, our work suggests stars may operate as both keystone consumers and keystone intimidators in the intertidal, and that non-consumptive interactions may explain large portions of their community impact and that of other keystone predators. Our study extends previous studies demonstrating behavioral and morphological responses of prey to stars by demonstrating long-term impacts of star presence on both feeding and reproduction of another predatory species, suggesting non-consumptive interactions may have long-term effects that are important to community dynamics. The importance of non-consumptive effects may be amplified by the relationship to predator density. Although studied at a small scale, our results suggest predator density had little effect on non-consumptive interactions and that the response to increasing predator density may be non-linear. Non-consumptive interactions may thus be an important mechanism through which small or fluctuating predator populations continually regulate community diversity.

Studying non-consumptive effects is inherently more challenging than studying direct effects of consumers. As a result, it is necessary to address potential methodological limitations. Although use of flowthrough systems and controls reduced the potential for water contamination to play a role in results while reducing variation among treatments due to wave action, local microclimate, or other factors (Menge et al. 1994, Helmuth et al. 2006, Broitman et al. 2009), the mesocosm nature of the study demands further work to determine if the strong non-consumptive effects we observed actually operate at scales that could lead to community impacts in natural settings. However, similar cues have been shown to have effects in turbulent marine and freshwater systems (Turner \& Montgomery 2003, Smee \& Weissburg 2006, Smee et al. 2008, 2010, Urriago et al. 2011). Determining encounter rates for prey and mobile predators is also difficult. Stars are primarily subtidal and are normally only observed when they have been stranded between tides. Individuals or small groups of stars are often observed aggregating at local sites (J. S. Gosnell pers. obs.) and for these reasons we elected to consider the impacts of 0,1 , and 2 stars in order to simulate conditions that commonly exist in field conditions. However, it should be noted star density can vary greatly in the field and the experiment did not fully encompass this natural variation. Prey also should be given the ability to employ the full range of adaptive responses to predator presence, including behaviors such as movement and habitat switching that may be precluded by smallscale studies in the lab or field. Future studies should attempt to address the impact of star presence on various intertidal species to fully comprehend the impacts of non-consumptive interactions on intertidal community structure. Previous work has suggested responses to predators may be influenced by feeding history. Although this experiment demonstrated responses of whelks to stars that were consuming whelks, we have obtained quantitatively similar results in experiments where stars were fed mussels (data not shown).

Non-consumptive effects and consumptive effects of predators may operate simultaneously and have varying impacts on potential prey. Non-consumptive interactions may alter prey traits, including those of other predators, at multiple temporal scales, including immediate changes in behavior or activity and long-term changes in growth or reproduction. These effects may exist in the near-absence of consumptive interactions and may play an important role in community regulation by keystone predators. The existence of primarily non-consumptive interactions suggest that studies of predator impacts on multiple prey species may better elucidate the interactions among these effects and reveal the full impacts of predators on communities. 
Acknowledgements. We thank Louise Stevenson, Jillian Davenport, Jamie DiPrima, Jennifer Chiu, and Taylor Scott for their aid in carrying out these experiments. Ryan Hechinger offered valuable assistance in determining methods to measure whelk reproductive tissue, and Jonathan Levine and 3 anonymous reviewers provided valuable feedback on the manuscript. Funding for this project was provided by a University of California, Santa Barbara Coastal Fund award. J.S.G. was supported by the National Science Foundation Graduate Research Fellowship and a National Defense Science and Engineering Graduate fellowship.

\section{LITERATURE CITED}

Abramoff M, Magelhaes P, Ram S (2004) Image processing with ImageJ. Biophotonics Int 11:36-42

- Abrams PA (2007) Defining and measuring the impact of dynamic traits on interspecific interactions. Ecology 88: 2555-2562

Alexander JE, Covich AP (1991) Predator avoidance by the fresh-water snail Physella virgata in response to the crayfish Procambarus simulans. Oecologia 87:435-442

Bates D, Maechler M, Bolker B (2011) lme4: linear mixedeffects model using $\mathrm{S} 4$ classes. $\mathrm{R}$ package version 0.999375-42. http://CRAN.R-project.org/package=lme4

> Berger KM, Gese EM, Berger J (2008) Indirect effects and traditional trophic cascades: a test involving wolves, coyotes, and pronghorn. Ecology 89:818-828

Bourdeau PE (2009a) Predator-induced behavioral and morphological plasticity in marine snails, Nucella spp. PhD dissertation, Stony Brook University, Stony Brook, NY

Bourdeau PE (2009b) Prioritized phenotypic responses to combined predators in a marine snail. Ecology 90: 1659-1669

Broitman BR, Szathmary PL, Mislan KAS, Blanchette CA, Helmuth B (2009) Predator-prey interactions under climate change: the importance of habitat vs body temperature. Oikos 118:219-224

- Bryan PJ, Mcclintock JB, Hamann M (1997) Behavioral and chemical defenses of marine prosobranch gastropod Calliostoma canaliculatum in response to sympatric seastars. J Chem Ecol 23:645-658

Crawley MJ (2007) The R book, 1st edn. Wiley, Chichester

$>$ Creel S, Christianson D (2009) Wolf presence and increased willow consumption by Yellowstone elk: implications for trophic cascades. Ecology 90:2454-2466

Creel S, Winnie JA, Christianson D (2009) Glucocorticoid stress hormones and the effect of predation risk on elk reproduction. Proc Natl Acad Sci USA 106:12388-12393

Escobar JB, Navarrete SA (2011) Risk recognition and variability in escape responses among intertidal molluskan grazers to the sun star Heliaster helianthus. Mar Ecol Prog Ser 421:151-161

Espoz C, Castilla JC (2000) Escape response of four Chilean intertidal limpets to seastar. Mar Biol 137:887-892

Freeman AS (2007) Specificity of induced defenses in Mytilus edulis and asymmetrical predator deterrence. Mar Ecol Prog Ser 334:145-153

> Hairston NG, Smith FE, Slobodkin LB (1960) Community structure, population control, and competition. Am Nat 94:421-425

> Hechinger RF, Lafferty KD, Mancini FT, Warner RR, Kuris AM (2008) How large is the hand in the puppet? Ecolog- ical and evolutionary factors affecting body mass of 15 trematode parasitic castrators in their snail host. Evol Ecol 23:651-667

> Helmuth B, Broitman BR, Blanchette CA, Gilman S and others (2006) Mosaic patterns of thermal stress in the rocky intertidal zone: implications for climate change. Ecol Monogr 76:461-479

Holt RD, Grover J, Tilman D (1994) Simple rules for interspecific dominance in systems with exploitative and apparent competition. Am Nat 144:741-771

Hothorn T, Bretz F, Westfall P (2008) Simultaneous inference in general parametric models. Biom J 50:346-363

> Hoverman JT, Relyea RA (2007) How flexible is phenotypic plasticity? Developmental windows for trait induction and reversal. Ecology 88:693-705

Ireland DH, Wirsing AJ, Murray DL (2007) Phenotypically plastic responses of green frog embryos to conflicting predation risk. Oecologia 152:162-168

Jiang L, Krumins JA (2006) Emergent multiple predator effects in an experimental microbial community. Ecol Res 21:723-731

Kishida O, Trussell GC, Nishimura K (2007) Geographic variation in a predator-induced defense and its genetic basis. Ecology 88:1948-1954

Laporte I, Muhly TB, Pitt JA, Alexander M, Musiani M (2010) Effects of wolves on elk and cattle behaviors: implications for livestock production and wolf conservation. PLoS ONE 5:e11954

Laurila A, Pakkasmaa S, Merila J (2006) Population divergence in growth rate and antipredator defences in Rana arvalis. Oecologia 147:585-595

Lima SL (1998) Nonlethal effects in the ecology of predatorprey interactions. Bioscience 48:25-34

Margolin AS (1964) The mantle response of Diodora aspera. Anim Behav 12:187-194

Marko PB, Palmer AR, Vermeij GJ (2003) Resurrection of Nucella ostrina (Gould, 1852), lectotype designation for $N$. emarginata (Deshayes, 1839), and molecular genetic evidence of Pleistocene speciation. Veliger 46:77-85

> Menge BA, Berlow EL, Blanchette CA, Navarrete SA, Yamada SB (1994) The keystone species concept - variation in interaction strength in a rocky intertidal habitat. Ecol Monogr 64:249-286

Miner BG, Sultan SE, Morgan SG, Padilla DK, Relyea RA (2005) Ecological consequences of phenotypic plasticity. Trends Ecol Evol 20:685-692

Morrison LW (1999) Indirect effects of phorid fly parasitoids on the mechanisms of interspecific competition among ants. Oecologia 121:113-122

> Navarrete SA, Menge BA (1996) Keystone predation and interaction strength: interactive effects of predators on their main prey. Ecol Monogr 66:409-429

> Navarrete SA, Menge BA, Daley BA (2000) Species interactions in intertidal food webs: prey or predation regulation of intermediate predators? Ecology 81:2264-2277

Nelson EH, Matthews CE, Rosenheim JA (2004) Predators reduce prey population growth by inducing changes in prey behavior. Ecology 85:1853-1858

Orrock JL, Dill LM, Sih A, Grabowski JH and others (2010) Predator effects in predator-free space: the remote effects of predators on prey. Open Ecol J 3:22-30

Paine RT (1966) Food web complexity and species diversity. Am Nat 100:65-75

Paine RT (1969) A note on trophic complexity and community stability. Am Nat 103:91-93 
Pangle KL, Peacor SD, Johannsson OE (2007) Large nonlethal effects of an invasive invertebrate predator on zooplankton population growth rate. Ecology 88:402-412

Peckarsky BL, Abrams PA, Bolnick DI, Dill LM and others (2008a) Revisiting the classics: considering nonconsumptive effects in textbook examples of predator-prey interactions. Ecology 89:2416-2425

Peckarsky BL, Kerans BL, Taylor BW, McIntosh AR (2008b) Predator effects on prey population dynamics in open systems. Oecologia 156:431-440

Phillips DW (1978) Chemical mediation of invertebrate defensive behaviors and the ability to distinguish between foraging and inactive predators. Mar Biol 49:237-243

Preisser EL, Bolnick DI, Benard MF (2005) Scared to death? The effects of intimidation and consumption in predatorprey interactions. Ecology 86:501-509

R Development Core Team (2010) R: a language and environment for statistical computing. R Foundation for Statistical Computing, Vienna

Relyea RA (2001) Morphological and behavioral plasticity of larval anurans in response to different predators. Ecology 82:523-540

Relyea RA (2003) How prey respond to combined predators: a review and an empirical test. Ecology 84:1827-1839

Sanford E (1999) Regulation of keystone predation by small changes in ocean temperature. Science 283:2095-2097

Sanford E (2002) The feeding, growth, and energetics of two rocky intertidal predators (Pisaster ochraceus and Nucella canaliculata) under water temperatures simulating episodic upwelling. J Exp Mar Biol Ecol 273:199-218

Sheriff MJ, Krebs CJ, Boonstra R (2009) The sensitive hare: sublethal effects of predator stress on reproduction in snowshoe hares. J Anim Ecol 78:1249-1258

Sih A, Englund G, Wooster D (1998) Emergent impacts of multiple predators on prey. Trends Ecol Evol 13:350-355

Sih A, Bolnick DI, Luttbeg B, Orrock JL and others (2010) Predator-prey naïveté, antipredator behavior, and the ecology of predator invasions. Oikos 119:610-621

Editorial responsibility: Antony Underwood, Sydney, New South Wales, Australia
Smee DL, Weissburg MJ (2006) Clamming up: Environmental forces diminish the perceptive ability of bivalve prey. Ecology 87:1587-1598

Smee DL, Ferner MC, Weissburg MJ (2008) Alteration of sensory abilities regulates the spatial scale of nonlethal predator effects. Oecologia 156:399-409

> Smee DL, Ferner MC, Weissburg MJ (2010) Hydrodynamic sensory stressors produce nonlinear predation patterns. Ecology 91:1391-1400

$>$ Storfer A, Sih A (1998) Gene flow and ineffective antipredator behavior in a stream-breeding salamander. Evolution 52:558-565

- Trussell GC, Smith LD (2000) Induced defenses in response to an invading crab predator: an explanation of historical and geographic phenotypic change. Proc Natl Acad Sci USA 97:2123-2127

> Trussell GC, Ewanchuk PJ, Bertness MD (2003) Traitmediated effects in rocky intertidal food chains: predator risk cues alter prey feeding rates. Ecology 84:629-640

Trussell GC, Ewanchuk PJ, Bertness MD, Silliman BR (2004) Trophic cascades in rocky shore tide pools: distinguishing lethal and nonlethal effects. Oecologia 139:427-432

Trussell GC, Ewanchuk PJ, Matassa CM (2006) The fear of being eaten reduces energy transfer in a simple food chain. Ecology 87:2979-2984

Turner AM, Montgomery SL (2003) Spatial and temporal scales of predator avoidance: experiments with fish and snails. Ecology 84:616-622

Urriago JD, Himmelman JH, Gaymer CF (2011) Responses of the black sea urchin Tetrapygus niger to its sea-star predators Heliaster helianthus and Meyenaster gelatinosus under field conditions. J Exp Mar Biol Ecol 399: $17-24$

Werner EE, Peacor SD (2003) A review of trait-mediated indirect interactions in ecological communities. Ecology 84:1083-1100

Zuur AF (2009) Mixed effects models and extensions in ecology with R. Springer, New York, NY

Submitted: July 18, 2011; Accepted: December 19, 2011

Proofs received from author(s): March 7, 2012 